ENCYCLOPÉDIE Encyclopédie berbère

BERBERE

$26 \mid 2004$

26 | Judaïsme - Kabylie

\title{
Kabylie : Le monde invisible
}

Conceptions populaires du sacré

E.B.

\section{OpenEdition}

Journals

Édition électronique

URL : http://journals.openedition.org/encyclopedieberbere/1441

DOI : 10.4000/encyclopedieberbere.1441

ISSN : 2262-7197

Éditeur

Peeters Publishers

Édition imprimée

Date de publication : 1 mai 2004

Pagination : 4085

ISBN : 2-7449-0452-X

ISSN : 1015-7344

Référence électronique

E.B., « Kabylie : Le monde invisible », Encyclopédie berbère [En ligne], 26 | 2004, document K19, mis en ligne le 01 juin 2011, consulté le 14 décembre 2020. URL : http://journals.openedition.org/ encyclopedieberbere/1441; DOI : https://doi.org/10.4000/encyclopedieberbere.1441

Ce document a été généré automatiquement le 14 décembre 2020.

(c) Tous droits réservés 


\section{Kabylie : Le monde invisible}

\section{Conceptions populaires du sacré}

\section{E.B.}

1 Voir notice C104 «Croyances; Puissances invisibles en Kabylie » (par H. Genevois, Encyclopédie Berbère XIV, 1994, p. 2133-2137) qui propose une synthèse des conceptions traditionnelles kabyles relatives aux forces surnaturelles et une typologie assez détaillée des agents : iessasen (" gardiens »), lmalaykkat (" anges »), linun (" génies »), et autres tiwkilin (« fées »).

2 En la matière, la source primaire essentielle reste le Fichier de Documentation Berbère (Fort-National/Alger) qui a publié de nombreuses notes sur le sujet; ces conceptions «populaires » - i.e. non conformes à l'orthodoxie islamique - du sacré et les pratiques qui leurs sont associées restent bien vivantes en Kabylie et pas uniquement en milieu féminin. Elles ont, pour l'essentiel, leurs racines dans le vieux fonds d'animisme préislamique des Berbères, avec cependant une influence non négligeable des sources coraniques et musulmanes, sans doute aussi du christianisme antique. Une influence (ou des convergences ?) des polythéismes punique et romain est également plus que probable (divinités domestiques, Lune, etc.), mais cette hypothèse reste à explorer précisément.

3 On consultera notamment:

- « Anges », FDB, 1951.

- « Mystagogie kabyle » (par J.-M. DALLET), FDB, 63, 1959.

- « Vues sur l'Au-delà... », FDB, 88, 1965.

- « Superstitions » I \& II, FDB, 97 et 100, 1968.

VOIR AUSSI notice « Religion » 


\section{BIBLIOGRAPHIE}

AIT FERROUKH F., 1997, « Le non-humain et ses rapports avec l'humain. Représentations kabyles du monde invisible ", Littérature orale arabo-berbère 25, p. 57-90.

DERMENGHEM E., 1954, Le culte des saints dans l'Islam maghrébin, Paris, Gallimard.

SERVIER J., 1985 ( $2^{\mathrm{e}}$ édition), Traditions et civilisations berbères. Les portes de l'année, Monaco, Éditions du Rocher.

INDEX

Mots-clés : Cosmogonie, Croyances, Ethnologie, Kabylie 